\title{
Masterpieces of Jeweller's Art in the Egyptian Style Made by Cartier in the Period of Art Deco
}

\author{
Alina Efimova \\ State Institute of Arts Studies \\ Moscow, Russia \\ E-mail: efi2007alina@mail.ru
}

\begin{abstract}
The following article tells about Egyptianesque motifs and designs of the pieces of jewellery created by the French house of Cartier in the Art Deco epoch. Firstly, the author pays attention to cultural and historical factors that caused development of egyptomania in the nineteenth century and the first quarter of the twentieth age. Secondly, the text includes the analysis of the stylistic features of body ornaments designed in the Egyptian style in 1920-s.
\end{abstract}

Keywords-Cartier; jewellery; egyptomania; Egyptianesque; the Egyptian Style; Art Deco

\section{INTRODUCTION}

Since the middle of the nineteenth century the French jewellery company Cartier has been known as one of the leaders on the world art jewellery market. During the second half of the nineteenth century and to this day such giants of jewelry-making as Cartier, Van Cleef \& Arpels, Tiffany \& $C^{o}$, Boucheron and others set the pace of development of jewelry art.

\section{EGYPTOMANIA: THE CULTURAL-HISTORICAL CONTEXT}

On the one hand, it is these European and American firms that determined the main trends in style and fashion in luxury body ornaments. On the other hand, their repertoire and stylistics of artworks were formed under the influence of comprehensive cultural processes. One such important process was the egyptomania caused by some important cultural-historical events that happened in the nineteenth century. Napoleon's Egyptian Campaign (1798-1801), the deciphering of Egyptian hieroglyphs by Jean-François Champollion (1822), the building of the Suez canal (18591869 ), the premiere of the opera Aida by Giuseppe Verdi (1871), - all of these achievements of the humans' mind and courage aroused universal interest in the Ancient Egyptian culture.

Thanks to the memoirs of contemporaries of those events, we know that the fashion for Egypt first emerged in the Napoleonic epoch. For instance, French jeweler and historian Henry Vever wrote that Napoleon's Egyptian Campaign started a vogue for objects made in the Egyptian style. At that time there were produced "pieces of jewellery decorated with scarabs, sphinxes and obelisks" [7. P. 16-17]. There are not many examples of such artwork in museum and private collections. Some of the rare pieces can be seen in the Victoria and Albert Museum in London or in the Museum of the Decorative Arts (Les Arts Décoratifs) in Paris. Analysis of the stylistic features of these objects reveals that they were produced without following the Ancient Egyptian jewellery tradition [2. P. 358. Cat. 218; 3. P. 379. Fig. 348]. In the first half of the nineteenth century, European artists did not have enough knowledge on the subject.

From the middle of that century onwards the situation began to change. A great role in this was played by the famous French Egyptologist and founder of the Egyptian museum in Cairo, Auguste Mariette. He organized a series of excavations that yielded brilliant results. In 1850, Mariette found the funeral complex Serapeum (tombs of the bulls of god Apis) and after nearly ten years, in 1859, he made the discovery of Queen Ahhotep's tomb. Both these discoveries expanded the knowledge about the Ancient Egyptian jeweller's art. Mariette initiated showing these amazing masterpieces of jewellery at the World Exhibitions of 1862 , 1867 and 1878. A great number of artists all over the world received an opportunity to see those ancient pieces of jewellery and study the techniques employed in making them. Jewellers received new sources of inspiration. As a result, in the second half of the nineteenth century there appeared many body ornaments fashioned in the Egyptian style. According to British scholar James Stevens Curl, "throughout the last four decades of the nineteenth century, and especially from 1880, there were thousands of examples of Egyptianising design: gold cuff-links featuring hieroglyphs and Egyptianesque figures, scarab-bracelets, brooches with Egyptian allusions, rings with sphinxes, Pharaonic heads, scarabs, and much else, and statuettes in the forms of naöphorus, Antinoüs, or other Egyptianising figures, survive in plenty" [1. P. 344]. Undisputed leaders of that trend in jewellery-making were such French masters as Émile-Désiré Philippe, Frédérique Boucheron, Cartier's workmasters, British jewellers Charles Horner, Robert Phillips, and those of the Americans firms Marcus \& $C^{o}$, Tiffany \& $C^{o}$.

The fashion for Egypt continued to flourish in the period of Art Nouveau. Thanks to the epistolary heritage of the famous French jeweller René Lalique, we know that he was interested in ancient jewels. There is a letter written by the 
French orientalist painter Georges Clairin to Lalique, his close friend, about recent successful excavations in Egypt organized in 1894-1895 by the French archeologist Jaques de Morgan. Thus, Clairin wrote, "My friend, I was constantly thinking of you. Believe me, this is not idle talk. I'll prove it when I bring you the sketches that I made specially for you. I am sure they may come in useful: cloisonné enamels, like the Japanese ones, in the colours of turquoise and lapis lazuli; and some dark-blue and reddishbrown gems of very superior quality, as far as I can judge. I also collected some cornelians and some other stones" [4. P. 93]. There were many Art Nouveau jewellers who were inspired to adopt Egyptianesque motifs and designs. Among them were such outstanding jewellers as the French masters Georges Fouquet, Léopold Gautrait, Alphonse Auger, Piel Fréres, the German master Georg Kleemann, and others.

\section{ThE EGYPTIAN STYLE IN THE PREVIOUS EPOCHS}

In other words, the tradition of using Ancient Egyptian motifs for creating jewels established by European and American jewellers in the first half of the nineteenth century was followed throughout the century and still continued at the beginning of the next age. Each epoch borrowed what was found important at the time. Body ornaments created in the second half of the century demonstrated an eclectic view on the Egyptian jeweller's art. However, it was about that time that the first serious attempts to analyze design of the ancient jewelry tradition were made. Jewellery-makers combined various elements for imitating archaic forms but, generally speaking, they did not aim to follow ancient models with precision. Art Nouveau jewellers were passionate about the symbolism of the Ancient Egyptian religion. All formal features of ornaments were treated in accordance with the fashion of the day. Only the best-known Egyptian motifs were absorbed, such as the scarab, the cobra, the lotus, or Queen Cleopatra. It can be pointed out here that the choice was made within the two key themes of Art Nouveau jewellery: the floral (and zoomorphic) one and that of the female silhouette.

\section{EGYPTIANESQUE MOTIFS AND DESIGNS OF ART DECO JEWELLERY}

However it was in the Art Deco epoch, in the 1920-1930$\mathrm{s}$, that the Ancient Egyptian theme was developed most consistently. Without any doubt the main reason for the universal passion for Egypt at the time was the discovery of King Tutankhamun's tomb in 1922. It is important to note that inside the tomb there was found a great number of jewellery items that greatly enlarged knowledge about the ancient tradition and helped to study it.

While the Art Deco style was being evolved, its creators actively searched for new forms which were borrowed from exotic art traditions, such as the art of the Maya and Ancient Egyptian art. What was it that jewellers of the 1920s-1930's found particularly appealing in the Ancient Egyptian heritage? First of all, it must have been the geometrical forms, the bright, localized colours, the wealth of ornamental forms and materials.
The Art Deco style and its love for Egypt found a truly remarkable embodiment in jewellery-making. The French house of Cartier was the leader in using ancient Egyptian motifs. Quite often this kind of luxury ornaments was made on commissions, which demonstrated how popular the Ancient Egyptian theme was among aristocrats and bohemians.

Jewellers did not make exact copies of Ancient Egyptian prototypes. They always created new pieces of the art of jewellery, in which they expressed the aesthetic views of their time. The House of Cartier created various types of Egyptianesque jewels: body ornaments, bracket clocks, toiletry cases, handbags. It is the first group of Cartier creations in this sequence that is the main object of attention in this paper.

If we try to analyze Art Deco jewels in the Egyptian style made by Cartier, it is possible to mark some characteristics common to the majority of these articles. Firstly, it is the method of creating an artistic image, which is based on contrast and opposition. Such contrasts are achieved by using materials absolutely different in their respective costs and places in the jewellery of the time. It means that there can be a combination, in a single individual piece of jewellery, of extra precious materials such as gold or platinum, diamonds, rubies, emeralds or sapphires with semi-precious stones such as lapis lazuli, cornelian or coral (the most important materials in Ancient Egypt but not in the first half of the twentieth century). In other words, Art Deco jewellers freely combined modern and ancient traditions. Their jewels were created as combination of ancient Egyptian forms and design created by the fantasy of the twentieth-century mind. For instance, an Art Deco master often used a piece of original old Egyptian faience. It could be a fragment of an ancient amulet, collar or statuette, that was put inside an Art Deco decorative frame.

The second important characteristic is paying equal attention to all elements of a jewel. A magnificent Art Deco frame, for instance, made of platinum and studded with diamonds, would turn a rather plain and not at all unique faience fragment (which looked like thousands of others) into something really important and exciting. On the other hand, thanks to the inclusion of an ancient original element with a thousand-years' history behind it, the entire piece of jewellery would be perceived as extra special in comparison.

For the workmasters of the House of Cartier the main method of creating Art Deco body ornaments in the Egyptian style was using a 'quotation'. Such a 'quotations' could be a fragment of an old Egyptian faience object which could be used in way absolutely different to that of the ancient tradition. Here again we can see free and bold treatment of the original material. A 'quotation' could also be made by borrowing traditional Egyptian forms, ornaments or using a colour scheme characteristic of Egyptian art. Another artistic method of Cartier was stylization. Both of method were nearly always combined.

Although Cartier's jewelers treated the ancient Egyptian theme freely, they knew Egypt's jewellery traditions well. They studied ancient jewels, the styles and techniques of 
jewellery-making, they travelled to Egypt, read books about Egyptian art, painting, reliefs, architecture and ornaments. It was that fundamental knowledge that enabled them to achieve successful results and create amazing pieces of decorative art.

\section{EXAMPLES}

One of the most significant jewel by Cartier made under the influence of the Egyptian art is the brooch named $S c a r a b^{l}$. It was created in 1924, when the world was going through an apogee of 'Tutankhamen-mania'. The jewel imitates a well-known type of Egyptian amulet known as the heart scarab. The wings are fragments of such an amulet dated from about the first millennium B.C. There are some similar pieces by Cartier's jewelers, with the central part made of authentic Egyptian faience ${ }^{2}$. This can be seen as a solution of the rather difficult task of creating a synthesis of the modern (i.e. Art Deco) and archaic traditions and breathing new life into ancient Egyptian aesthetics.

Another beautiful brooch, the Chorus, was done in the same manner in $1925^{3}$. It incorporates the faience head of a falcon that was part of tan accomplished work of art.

Sometimes, French masters used not just a detail of an archaic jewel but whole faience amulets of goddesses Isis or Seckhmet. Quite often these little statuettes had defects and loses, which were compensated for in different ways. Thus, in 1925 Cartier created two brooches in the form of the lion goddess Seckhmet ${ }^{4}$. A faience artifact, decorated with a precious stone, plays the central role in the composition.

The method of stylization could be illustrated by the brooch called Pylon made in $1927^{5}$. It looks like a traditional Egyptian temple flanked with an obelisk and a palm tree. The composition was inspired by the famous temples of Luxor and Karnak. There is no parallel of such piece of jewellery in the Egyptian tradition, therefore it is a fruit of twentieth-century artistic imagination.

\section{CONCLUSION}

The selected examples described above illustrate the principal methods used by the House of Cartier in creating jewellery in the Egyptian style. During the Art Deco period,

\footnotetext{
${ }^{1}$ Brooch Scarab, 1924, Cartier, London; gold, platinum, Egyptian faience (dated from about the first millennium B.C.), smoky quartz, diamonds, emerald, enamel; $13 \times 5 \times 2 \mathrm{~cm}$; Collection of Cartier, Inv. Nr. CL32A24.

${ }^{2}$ Brooch Scarab 1925, Cartier, London; gold, platinum, Egyptian faience (dated from about the first millennium B.C.), diamonds, emerald, ruby, citrine, onyx; $12.4 \times 5.5 \times 1.9 \mathrm{~cm}$; Collection of Cartier, Inv. $\mathrm{Nr}$. CL264A25.

${ }^{3}$ Brooch Chorus, 1925, Cartier, Paris; gold, platinum, Egyptian faience (dated from about the first millennium B.C.), diamonds, emerald, coral, onyx, enamel; $4.5 \times 7.1 \mathrm{~cm}$; Collection of Cartier, Inv. Nr. CL263A25.

${ }^{4}$ Brooch Seckhmet, 1925, Cartier, Paris; gold, platinum, Egyptian faience, diamonds, emerald, ruby, onyx, enamel; Auction Sotheby's, New York, 11 December 2013, lot 406;

Brooch Seckhmet, 1925, Cartier, Paris; gold, platinum, Egyptian faience (dated from about the first millennium B.C.), diamonds, emerald, ruby, onyx, enamel; $8.3 \times 3.6 \mathrm{~cm}$; Collection of Cartier, Inv. Nr. CL278A25.

${ }^{5}$ Brooch Pylon, 1927, Cartier, Paris; platinum, diamonds; $1.8 \times 2.5 \mathrm{~cm}$; Collection of Cartier, Inv. Nr. CL318A27.
}

the French firm made more pieces of jewellery and luxury objects inspired by Ancient Egypt than all other European and American companies. Brooches, pendants, collars, diadems, tie pins by Cartier are always original and expressive. The Egyptian theme continued to feature in Cartier's repertoire long after the end of the Art Deco epoch. Thus, they were still creating Egyptianesque body ornaments as late as the 1990s.

\section{REFERENCES}

[1] J.St. Curl, "The Egyptian Revival : Ancient Egypt as the Inspiration for Design Motifs in the West," London, New York, 2005.

[2] “Egyptomania: L’Égypt dans l'art occidental : 1730-1930” : exhib. cat. / Musée du Louvre. 20 janvier - 18 avril 1994, Paris, 1994.

[3] Ch. Gere, J. Rudoe, "Jewellery in the Age of Queen Victoria. A Mirror to the World" / The British Museum, London, 2010.

[4] R. Lalique, "Correspondance d'un bijoutier Art Nouveau. 18901908," Lausanne, 2007.

[5] A. Mariette, "L'Exposition universelle de Paris, 1878. La Galerie de l'Égypte ancienne à l'exposition rétrospective du Trocadéro," Paris, 1878.

[6] A. Mariette, "Le Sérapéum de Memphis," Paris, 1857-1866.

[7] H. Vever, "La bijouterie française au XIXe siècle (1800-1900)," Paris, 1906-1908. 3 vols. T. 1. 